\title{
Analisis Pengaruh Dana Pihak Ketiga (DPK), Non Performing Financing (NPF) dan Return On Asset (ROA) Terhadap Pembiayaan di PT Bank Muamalat Indonesia Tbk
}

\author{
Ida Puspitarini*, Vita Fidya Utami \\ Institut Agama Islam Negeri Purwokerto, Indonesia \\ ida.nayaraya@gmail.com
}

Copyright (C) 2021 The Author

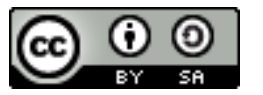

This is an open access article

Under the Creative Commons Attribution-ShareAlike 4.0 International License

\begin{abstract}
This study aims to determine how the influence of Third Party Funds (DPK), Non Performing Financing (NPF) and Return On Assets (ROA) on Financing at PT Bank Muamalat Indonesia Tbk Period 2016-2020. The data used in this study is secondary data, namely the quarterly Financial Statements of PT Bank Muamalat Indonesia for 2016-2020 which were obtained through the official website of PT Bank Muamalat Indonesia Tbk. Data analysis using multiple linear regression analysis techniques which previously tested the classical assumption test. Hypothesis testing is done by using $t$ test for partial testing, $F$ test for simultaneous testing (together) and the Coefficient of Determination (R2). During the observation period, it shows that the research data is normally distributed. Based on the classical assumption test, autocorrelation symptoms were found in the variables from the classical assumption test, so it was necessary to transform the data. The results showed that: 1) DPK had a partial positive effect on Financing at PT Bank Muamalat Indonesia Tbk, 2) NPF had no partially negative effect on Financing at PT Bank Muamalat Indonesia Tbk, and 3) ROA had no partial positive effect on Financing at PT Bank Muamalat Indonesia Tbk. PT Bank Muamalat Indonesia Tbk, 4) DPK, NPF and ROA have no effect on financing at PT Bank Muamalat Indonesia Tbk.
\end{abstract}

Keywords: third party funds (DPK); non performing financing (NPF); return on assets (ROA); financing

\begin{abstract}
ABSTRAK
Penelitian ini bertujuan untuk mengetahui bagaimana pengaruh Dana Pihak Ketiga (DPK), NonPerforming Financing (NPF) dan Return On Asset (ROA) terhadap Pembiayaan di PT Bank Muamalat Indonesia Tbk Periode 2016-2020. Data yang digunakan dalam penelitian ini merupakan data sekunder yaitu Laporan Keuangan triwulan PT Bank Muamalat Indonesia tahun 2016-2020 yang diperoleh melalui website resmi PT Bank Muamalat Indonesia Tbk. Analisis data menggunakan teknik analisis regresi linier berganda yang mana sebelumnya dilakukan uji asumsi klasik. Pengujian hipotesis dilakukan dengan menggunakan uji t untuk pengujian secara parsial, uji F untuk pengujian secara simultan (bersama-sama) dan Koefisien Determinasi $\left(\mathrm{R}^{2}\right)$. Selama periode pengamatan, menunjukan bahwa data penelitian berdistribusi normal. Berdasarkan uji asumsi klasik ditemukan gejala autokorelasi pada variabel dari uji asumsi klasik sehingga perlu dilakukan transformasi data. Hasil penelitian menunjukkan bahwa: 1) DPK berpengaruh positif secara parsial terhadap Pembiayaan di PT Bank Muamalat Indonesia
\end{abstract}


Tbk, 2) NPF tidak berpengaruh negatif secara parsial terhadap Pembiayaan di PT Bank Muamalat Indonesia Tbk, dan 3) ROA tidak berpengaruh positif secara parsial terhadap Pembiayaan di PT Bank Muamalat Indonesia Tbk, 4) DPK, NPF dan ROA tidak berpengaruh secara bersama-sama terhadap Pembiayaan di PT Bank Muamalat Indonesia Tbk.

Kata Kunci: dana pihak ketiga (DPK); non performing financing (NPF); return on assets (ROA); pembiayaan

\section{A. PENDAHULUAN}

Bank adalah pelayanan masyarakat dan wadah perantara keuangan masyarakat. Karena itu, bank harus selalu berada ditengah masyarakat agar arus uang dari masyarakat yang kelebihan dapat ditampung dan disalurkan pada masyarakat yang kekurangan. Kepercayaan masyarakat akan keberadaan bank dan keyakinan masyarakat bahwa bank akan menyelenggarakan sebaikbaiknya permasalahan keuangannya, merupakan suatu keadaan yang diharapkan semua bank (Aziza dan Mulazid, 2017).

Kehadiran bank syariah diantara bank konvensional adalah untuk menawarkan sistem alternatif bagi umat islam yang ingin mendapatkan layanan pengelolaan keuangan yang baik menurut islam tanpa harus melanggar larangan riba. Pengembangan system bank syariah di Indonesia dilakukan dalam kerangka dual-banking system, yang bertujuan untuk menghadirkan alternatif jasa bank yang semakin lengkap kepada masyarakat Indonesia (Riyadi dan Rafii, 2018).

Pembiayaan merupakan aktivitas bank syariah dalam menyalurkan dana kepada pihak lain selain bank berdasarkan prinsip syariah. Penyaluran dana dalam bentuk pembiayaan didasarkan pada kepercayaan yang diberikan oleh pemilik dana kepada pengguna dana (Pasaribu, 2019). Pembiayaan merupakan faktor yang mempengaruhi profitabilitas bank. Menurut Dendawijaya (2005) dalam Khotimah (2019) kredit atau pembiayaan merupakan kegiatan atau aktivitas yang terbesar dari perbankan.

Dana Pihak Ketiga (DPK) atau simpanan dana yang dipercayakan oleh masyarakat kepada bank berdasarkan perjanjian penyimpanan dana dalam bentuk giro, tabungan, deposito dan atau bentuk lainnya yang dipersamakan dengan itu. Sumber-sumber penghimpunan dana (tidak termasuk modal) perbankan syariah secara umum didominasi oleh Dana Pihak Ketiga (DPK) (Aziza dan Mulazid, 2017). Dana yang dimiliki oleh bank juga merupakan salah satu faktor yang dapat mempengaruhi tingkat profitabilitas. Dana yang dimiliki bank sangat penting untuk perencanaan investasi dan melakukan kegiatan usahanya (Khotimah, 2019).

Non Performing Financing (NPF) atau Non Performing Loan (NPL) adalah perbandingan antara kredit atau pembiayaan bermasalah dengan total kredit atau pembiayaan yang diberikan. Semakin tinggi rasio ini menunjukan ketidakmampuan suatu bank dalam mengelola kredit atau pembiayaan bermasalahnya, tentunya hal tersebut akan menurunkan tingkat kepercayaan diri suatu bank serta kehati-hatian dalam melakukan kegiatan usahanya pada periode selanjutnya seperti penyaluran pembiayaan (Setiawan dan Indriani, 2016).

Hanafi dan Halim menyatakan Return On Asset (ROA) dapat mengukur kemampuan perusahaan dalam menghasilkan laba dengan menggunakan kekayaan yang dimiliki perusahaan setelah disesuaikan dengan biaya-biaya yang dikeluarkan untuk mendanai aset tersebut. Oleh 
karena itu, ROA merupakan indikator yang tepat dalam mengukur kinerja bank (Setiawan dan Indriani, 2016).

\section{B. TELAAH PUSTAKA}

\section{Dana Pihak Ketiga (DPK)}

Surat Edaran Bank Indonesia No. 6/23/DPNP tanggal 31 Mei 2004 Dana Pihak Ketiga (DPK) adalah dana yang dipercayakan oleh masyarakat kepada bank dapat berupa Giro, Tabungan, dan Deposito.

a. Giro

Giro menurut undang-undang perbankan nomor 21 tahun 2008 pasal 1 ayat 23, "Giro adalah Simpanan berdasarkan Akad wadi'ah atau Akad lain yang tidak bertentangan dengan Prinsip Syariah yang penarikannya dapat dilakukan setiap saat dengan menggunakan cek, bilyet giro, sarana perintah pembayaran lainnya, atau dengan perintah pemindahbukuan."

b. Tabungan

Tabungan menurut undang-undang perbankan nomor 21 tahun 2008 pasal 1 ayat 21, "Tabungan adalah simpanan berdasarkan Akad wadi'ah atau Investasi dana berdasarkan Akad mudharabah atau Akad lain yang tidak bertentangan dengan Prinsip Syariah yang penarikannya hanya dapat dilakukan menurut syarat dan ketentuan tertentu yang disepakati, tetapi tidak dapat ditarik dengan cek, bilyet giro, dan/atau alat lainnya yang dipersamakan dengan itu." Tabungan dapat ditarik setiap saat dengan menggunakan buku tabungan, slip penarikan, ATM, surat kuasa dan sarana lainnya.

c. Deposito

Deposito menurut undang-undang perbankan nomor 21 tahun 2008 pasal 1 ayat 22, "Deposito adalah Investasi dana berdasarkan Akad mudharabah atau Akad lain yang tidak bertentangan dengan Prinsip Syariah yang penarikannya hanya dapat dilakukan pada waktu tertentu berdasarkan Akad antara Nasabah Penyimpan dan Bank Syariah dan/atau UUS."

\section{Non Performing Financing (NPF)}

Non Performing Financing (NPF) merupakan rasio yang dipergunakan untuk mengukur kemampuan bank dalam mengukur risiko kegagalan pengembalian pinjaman oleh debitur (pihak yang menerima pembiayaan) (Pasaribu, 2019). Non Performing Financing (NPF) adalah rasio antara pembiayaan yang bermasalah dengan total pembiayaan yang disalurkan oleh bank syariah. Berdasarkan kriteria yang sudah ditetapkan oleh Bank Indonesia yang termasuk dalam NPF adalah pembiayaan kurang lancar, diragukan dan macet. Dalam peraturan Bank Indonesia Nomor 8/21/PBI/2006 tentang Penilaian Kualitas Bank Umum yang melaksanakan kegiatan usaha berdasarkan Prinsip Syariah Pasal 9 Ayat 2, bahwa kualitas aktiva produktif dalam bentuk pembiayaan dibagi dalam 5 golongan yaitu lancar (L), dalam perhatian khusus (DPK), kurang lancar (KL), diragukan (D), macet (M). Non Performing Financing (NPF) akan berdampak pada menurunnya tingkat bagi hasil yang dibagikan pada pemilik dana (Aziza dan Mulazid, 2017). 


$$
\mathrm{NPF}=\frac{\text { Pembiayaan Bermasalah }}{\text { Total Pembiayaan }} \times 100 \%
$$

\section{Return On Asset (ROA)}

Return On Assets (ROA) adalah rasio yang menggambarkan kemampuan bank dalam mengelola dana yang diinvestasikan dalam keseluruhan aktiva yang menghasilkan keuntungan. Semakin tinggi ROA maka akan menunjukkan semakin efisien operasional dari suatu perusahaan, begitupun sebaliknya rendahnya ROA dapat disebabkan oleh banyaknya aset perusahaan yang menganggur (Anwar dan Miqdad, 2017).

$$
\text { ROA }=\frac{\text { Laba Setelah Bunga dan Pajak }}{\text { Total Asset }} \times 100 \%
$$

\section{Pembiayaan}

Pembiayaan adalah fasilitas yang diberikan oleh bank syariah kepada masyarakat yang membutuhkan untuk menggunakan dana yang telah dikumpulkan oleh bank syariah dari masyarakat yang surplus dana (Muhammad, 2004: 7).

\section{Penelitian Terdahulu}

Penelitian yang dilakukan oleh Rina Destiana (2016) menyatakan bahwa DPK berpengaruh positif terhadap pembiayaan mudharabah dan musyarakah. Penelitian yang dilakukan oleh Selamet Riyadi dan Rais Muhcamad Rafii (2018) menyatakan bahwa DPK berpengaruh signifikan dan berpengaruh positif terhadap Pembiayaan Murabahah pada Bank Umum Syariah.

Penelitian yang dilakukan oleh Riska Robiyanti Erlita (2016) menyatakan bahwa NPF Bank Umum Syariah berpengaruh negatif dan signifikan terhadap pembiayaan. Penelitian yang dilakukan oleh Ulin Nuha Aji Setiawan dan Astiwi Indriani (2016) juga menyatakan bahwa NPF berpengaruh negatif signifikan terhadap pembiayaan.

Penelitian yang dilakukan oleh Riska Robiyanti Erlita (2016) menyatakan bahwa ROA Bank Umum Syariah berpengaruh positif dan signifikan terhadap pembiayaan. Penelitian yang dilakukan oleh Chairul Anwar dan Muhammad Miqdad (2017) yang menyebutkan bahwa variabel Return On Assets (ROA) berpengaruh positif berpengaruh positif dan tidak signifikan terhadap pembiayaan mudharabah pada Bank Umum Syariah di Indonesia tahun 2008-2012.

\section{Kerangka Konseptual}

Berdasarkan landasan teori dan hasil penelitian sebelumnya serta permasalahan yang telah dikemukakan, maka sebagai dasar perumusan hipotesis berikut disajikan kerangka konseptual yang dituangkan dalam model penelitian berikut. 


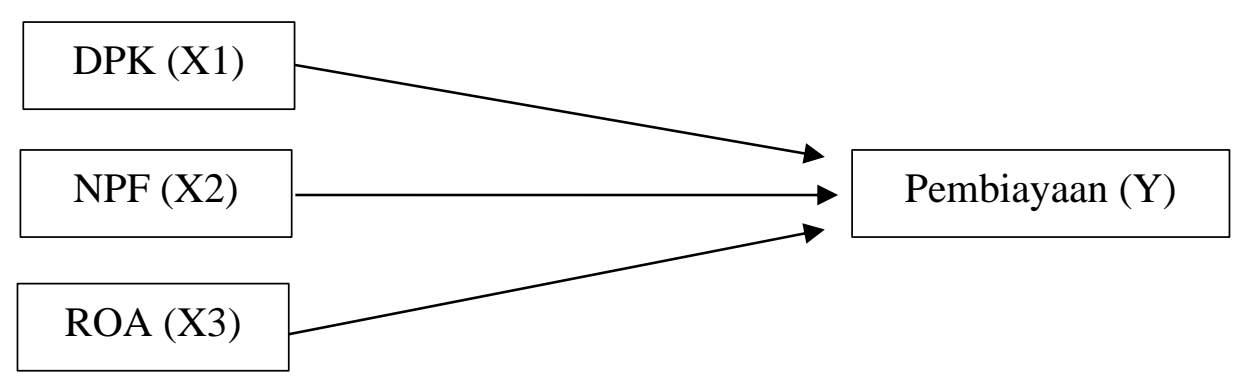

Gambar 1. Kerangka Konseptual

Dana Pihak Ketiga (DPK) berpengaruh positif terhadap pembiayaan yaitu jika DPK mengalami kenaikan maka pembiayaan juga akan mengalami kenaikan. Non Performing Financing (NPF) berpengaruh negative terhadap pembiayaan, dimana jika NPF mengalami kenaikan, maka pembiayaan yang disalurkan akan mengalami penurunan begitu juga sebaliknya. Return On Asset (ROA) berpengaruh positif terhadap pembiayaan, jika ROA mengalami kenaikan maka pembiyaan juga akan mengalami kenaikan.

$\mathrm{H}_{1}$ : Dana Pihak Ketiga (DPK) berpengaruh positif terhadap Pembiayaan di PT Bank Muamalat Indonesia Tbk.

$\mathrm{H}_{2}$ : Non Performing Financing (NPF) berpengaruh negatif terhadap Pembiayaan di PT Bank Muamalat Indonesia Tbk.

$\mathrm{H}_{3}$ : Return on Assets (ROA) berpengaruh positif terhadap Pembiayaan di PT Bank Muamalat Indonesia Tbk.

\section{METODE PENELITIAN}

1. Tempat dan Waktu Penelitian

Tempat penelitian yang dilakukan yaitu di PT Bank Muamalat Indonesia Tbk. PT Bank Muamalat Indonesia Tbk dipilih sebagai tempat penelitian karena merupakan bank syariah pertama yang ada di Indonesia dan telah berhasil melalui krisis ekonomi yang terjadi di Indonesia pada tahun 1998.

2. Populasi dan Sampel

Populasi dari penelitian ini adalah PT Bank Muamalat Indonesia Tbk. Teknik pengambilan sampel dalam penelitian ini menggunakan total sampling, karena jumlah populasi dalam penelitian ini kurang dari 30, maka penarikan sampel dilakukan secara keseluruhan. Bagian dari sampel dalam penelitian ini yakni Laporan Keuangan Triwulanan Bank Muamalat Indonesia Triwulan I tahun 2016 sampai dengan Triwulan III tahun 2020.

3. Metode Analisis Data

a. Uji Statistik Deskriptif

Statistik deskriptif adalah statistik yang digunakan untuk menganalisis data dengan cara mendeskripsikan atau menggambarkan data yang telah terkumpul sebagaimana adanya tanpa bermaksud membuat kesimpulan yang berlaku untuk umum atau 
generalisasi. Dalam statistik deskriptif juga dapat dilakukan mencari kuatnya hubungan antara variabel melalui analisis korelasi, melakukan analisis regresi, dan membuat perbandingan dengan membandingkan rata-rata data sampel atau populasi (Sugiyono, 2016: 147-148).

b. Uji Asumsi Klasik

1) Uji Normalitas

Uji normalitas dimaksudkan untuk menguji apakah nilai residual yang telah distandarisasi pada model regresi berdistribusi normal atau tidak. Nilai residual dikatakan berdistribusi normal jika nilai residual terstandarisasi tersebut sebagian besar mendekati nilai rata-ratanya (Suliyanto, 2011: 69). Mendeteksi apakah data berdistribusi normal atau tidak dapat diketahui dengan menggambarkan penyebaran data melalui sebuah grafik. Jika data menyebar disekitar garis diagonal dan mengkuti arah garis diagonalnya, model regresi memenuhi asumsi normalitas. Uji kenormalan data juga bisa dilakukan tidak berdasarkan grafik, misalya dengan Uji Kolmogorof-Smirnov (Muhammad, 2017: 75).

2) Uji Multikolinieritas

Multikolinieritas adalah adanya lebih dari satu hubungan linier yang sempurna. Dalam regresi tidak boleh terjadi multikolinieritas karena menurut Ragner Frish apabila terjadi multikolinieritas apalagi kolinier yang sempurna (koefisien korelasi antara variabel bebas $=1$ ) maka koefisien regresi dari variabel bebas tidak dapat ditentukan dan standar erornya tidak terhingga (Muhammad, 2017: 75). Uji multikolinieritas untuk mengetahui apakah pada model regresi ditemukan adanya korelasi antara variabel independen. Jika terjadi korelasi, terdapat masalah multikolinieritas yang harus diatasi. Untuk mendeteksi ada atau tidaknya gejala multikolinieritas di dalam model regresi ini dengan melihat nilai Variance Inflation Factor (VIF).

3) Uji Heteroskedastisitas

Uji asumsi heteroskedastisitas bertujuan untuk menguji apakah dalam model regresi linier terjadi ketidaksamaan varian dari residual satu pengamatan ke lainnya. Jika varian dan residual satu pengamatan ke pengamatan lain tetap, maka disebut Homokedastisitas dan jika berbeda disebut heteroskedastisitas. Dasar pengambilan keputusan ada tidaknya heteroskedastisitas (Imam Ghozali, 2005), sebagai berikut :

a) Jika ada pola tertentu seperti titik-titik yang ada membentuk suatu pola teratur (bergelombang, melebar kemudian menyempit), maka terjadi heteroskedastisitas;

b) Jika tidak ada pola tertentu yang jelas serta titik-titik menyebar di atas dan di bawah angka 0 sumbu $\mathrm{Y}$, maka tidak terjadi heteroskedastisitas.

Model regresi yang baik adalah tidak terjadi heteroskedastisitas. Uji heteroskedastisitas dalam penelitian ini dengan cara melihat grafik plot. 
4) Uji Autokorelasi

Uji asumsi autukorelasi bertujuan untuk menguji apakah dalam suatu model regresi linier ada korelasi antara kesalahan pengganggu pada periode t dengan kesalahan pengganggu pada periode t-1 (Imam Ghozali, 2005). Dalam penelitian ini menggunakan Uji Runs Test.

c. Analisis Regresi Linier Berganda

Analisis regresi linear berganda adalah analisis ketergantungan dari satu atau lebih variabel independen terhadap satu variabel dependen dengan tujuan untuk menduga atau memprediksi nilai rata-rata populasi berdasarkan nilai-nilai variabel independennya. Analisis regresi linear berganda digunakan untuk mengetahui hubungan pengaruh dua atau lebih variabel independen terhadap variabel dependen (Supranto, 2008: 196).

Analisis regresi linear berganda dalam penelitian ini untuk mengetahui apakah terdapat pengaruh DPK, NPF dan ROA terhadap pembiayaan.

Persamaan regresinya yaitu:

$$
\mathrm{Y}=\alpha+\beta_{1} \mathrm{X}_{1}+\beta_{2} \mathrm{X}_{2}+\beta_{3} \mathrm{X}_{3}+\mathrm{e}
$$

Dimana:

$\mathrm{Y}=$ Variabel Pembiayaan

$a=$ Konstanta

$\beta_{1}=$ Koefisien regresi 1

$\beta_{2}=$ Koefisien regresi 2

$\beta_{3}=$ Koefisien regresi 3

$\mathrm{X}_{1}=$ Variabel DPK

$\mathrm{X}_{2}=$ Variabel NPF

$\mathrm{X}_{3}=$ Variabel ROA

$\mathrm{e}=$ eror

\section{d. Pengujian Hipotesis}

1) Uji Parsial (Uji t)

Uji Statistik $t$ pada dasarnya menunjukkan seberapa jauh satu variabel independen secara individual atau parsial dapat menerangkan variasi variabel terikat (Ovami dan Thohari, 2018). Uji t digunakan untuk mengetahui ada tidaknya pengaruh masing-masing variabel independen secara individual (parsial) terhadap variabel dependen yang diuji pada tingkat signifikansi 0,05. Apabila probabilitas lebih kecil dari 0,05 maka hasilnya terdapat pengaruh dari variabel independen secara individual terhadap variabel dependen (Aziza dan Mulazid, 2017).

2) Uji Simultan (Uji F)

Uji statistik F digunakan untuk mengetahui apakah variabel independen secara bersama-sama berpengaruh terhadap variabel dependen. Atau untuk mengetahui 
apakah model regresi dapat digunakan untuk memprediksi variabel dependen atau tidak (Aziza dan Mulazid, 2017).

3) Uji Koefisien Determinasi $\left(\mathrm{Uji} \mathrm{R}^{2}\right)$

Uji $\mathrm{R}^{2}$ berguna untuk mengukur seberapa jauh kemampuan model dalam menerangkan variasi variabel dependen. Nilai koefisien determinasi adalah antara nol dan satu. Nilai $R^{2}$ yang kecil berarti kemampuan variabel-variabel independen dalam menjelaskan variasi variabel dependen amat terbatas. Nilai yang mendekati satu berarti variabel-variabel independen memberikan hampir semua informasi yang dibutuhkan untuk memprediksi variasi-variabel dependen (Ghozali, 2005).

\section{ANALISIS DATA DAN PEMBAHASAN}

\section{Uji Statistik Deskriptif}

Tabel 1. Hasil Uji Deskriptif

Descriptive Statistics

\begin{tabular}{cccccc}
\hline & N & Minimum & Maximum & Mean & $\begin{array}{c}\text { Std. } \\
\text { Deviation }\end{array}$ \\
\hline X1DPK & 19 & 38597650 & 48686342 & 43480917,47 & 3053028,776 \\
X2NPF & 19 &, 88 & 4,98 & 3,4668 & 1,25029 \\
X3ROA & 19 &, 02 &, 49 &, 1321 &, 12421 \\
YPEMBIAYAAN & 19 & 28763784 & 41906958 & 35902936,74 & 4867572,083 \\
Valid N (listwise) & 19 & & & & \\
\hline
\end{tabular}

Pada Tabel 1 di atas, menunjukan jumlah data yang digunakan berjumlah 19 sampel selama periode Triwulan I 2016 - Triwulan III 2020. Dari hasil perhitungan diketahui nilai minimum Dana Pihak Ketiga (DPK) sebesar 38.597.650 yang diperoleh pada periode 2020 triwulan II. Nilai maksimum DPK sebesar 48.686.342 yang diperoleh pada periode 2017 triwulan IV. Nilai mean atau rata-rata DPK sebesar 43.480.917,47 dengan standar deviasinya sebesar 3.053.028,776. Nilai standar deviasi lebih kecil dari nilai mean periode 2016-2020, hal ini mengartikan bahwa tidak terjadi kesenjangan yang cukup besar pada sebaran nilai rasio DPK terendah dan tertinggi pada periode Triwulan I 2016 - Triwulan III 2020.

Non Performing Financing (NPF) memiliki nilai minimum sebesar 0,88 yang diperoleh di tahun 2018 pada triwulan II. Nilai maksimum NPF sebesar 4,98 yang diperoleh di tahun 2020 pada triwulan I. Nilai Mean atau rata-rata NPF sebesar 3,4668. Nilai standar deviasinya sebesar 1,25029. Nilai standar deviasi lebih kecil dari nilai mean pada periode tahun 2016-2019, hal ini mengartikan bahwa tidak terjadi kesenjangan yang cukup besar pada sebaran nilai rasio NPF terendah dan tertinggi pada periode Triwulan I 2016 Triwulan III 2020.

Return On Asset (ROA) memiliki nilai minimum sebesar 0,02 yang diperoleh di tahun 
2019 pada triwulan I, II, dan III. Nilai maksimum ROA sebesar 0,49 yang diperoleh di tahun 2018 Triwulan II. Nilai mean atau rata-rata ROA sebesar 0,1321 dan nilai standar deviasinya sebesar 0,12421. Nilai standar deviasi lebih kecil dari nilai mean pada periode tahun 2016-2020, hal ini mengartikan bahwa tidak terjadi kesenjangan yang cukup besar pada sebaran nilai rasio ROA terendah dan tertinggi pada periode Triwulan I 2016 Triwulan III 2020.

Pembiayaan memiliki nilai minimum sebesar 28.763.784 yang diperoleh di tahun 2020 pada Triwulan III. Nilai maksimum Pembiayaan sebesar 41.906 .958 di tahun 2018 Triwulan I. Nilai mean atau rata-rata Pebiayaan sebesar 35.902.936,74 dan nilai standar deviasinya sebesar 4.867.572,083. Nilai standar deviasi lebih kecil dari nilai mean pada periode tahun 2016-2019, hal ini mengartikan bahwa tidak terjadi kesenjangan yang cukup besar pada sebaran nilai rasio Pembiayaan terendah dan tertinggi pada periode Triwulan I 2016 - Triwulan III 2020.

2. Uji Asumsi Klasik

a) Uji Normalitas

Tabel 2. Hasil Uji Normalitas

One-Sample Kolmogorov-Smirnov Test

\begin{tabular}{llr}
\hline \multicolumn{1}{c}{$\mathrm{N}$} & \multicolumn{2}{c}{$\begin{array}{c}\text { Unstandardized } \\
\text { Residual }\end{array}$} \\
\hline Normal Parameters ${ }^{\mathrm{a}, \mathrm{b}}$ & Mean & 18 \\
& Std. Deviation & 60611,7080285 \\
Most Extreame & Absolute &, 110 \\
Differences & Positive &, 110 \\
Kolmogorov-Smirnov Z & Negative &, 082 \\
Asymp. Sig. (2-tailed) & &, 987 \\
\hline a. Test distribution is Normal. & \\
\hline b. Calculated from data. & \\
\hline
\end{tabular}

Dari hasil output uji Kolmogorov-Smirnov diatas diperoleh nilai sig. sebesar 0,981 yang mana nilai 0,981 >0,05. Dengan demikian dapat disimpulkan model regresi dalam penelitian ini terdistribusi normal. 
b) Uji Multikolinieritas

Tabel 3: Hasil Uji Multikolinieritas

Coefficients $^{\text {a,b }}$

\begin{tabular}{|c|c|c|c|c|c|c|c|c|}
\hline \multirow{2}{*}{\multicolumn{2}{|c|}{ Model }} & \multicolumn{2}{|c|}{ Unstandardized Coefficients } & \multirow{2}{*}{$\begin{array}{c}\text { Standardized } \\
\text { Coefficients } \\
\text { Beta } \\
\end{array}$} & \multirow[t]{2}{*}{$\mathrm{t}$} & \multirow[t]{2}{*}{ Sig. } & \multicolumn{2}{|c|}{$\begin{array}{c}\text { Collinearity } \\
\text { Statistics }\end{array}$} \\
\hline & & B & Std. Error & & & & Tolerance & VIF \\
\hline \multirow{3}{*}{1} & DPK & ,762 & ,051 & ,968 & 14,872 & , 000 & ,455 & 2,199 \\
\hline & NPF & 128626,460 & 426620,410 & ,020 & ,302 & ,767 & ,428 & 2,335 \\
\hline & ROA & 2143477,553 & 4262878,064 & ,026 &, 503 & 622 & ,699 & 1,431 \\
\hline \multicolumn{9}{|c|}{ a. Dependent Variable: PEMBIAYAAN } \\
\hline
\end{tabular}

Dari hasil output uji Multikolinieritas diatas nilai VIF masing-masing variabel bebas $<10,00$. Dengan demikian dapat disimpulkan model regresi dalam penelitian ini tidak terjadi Multikolinieritas.

c) Uji Heteroskedastisitas

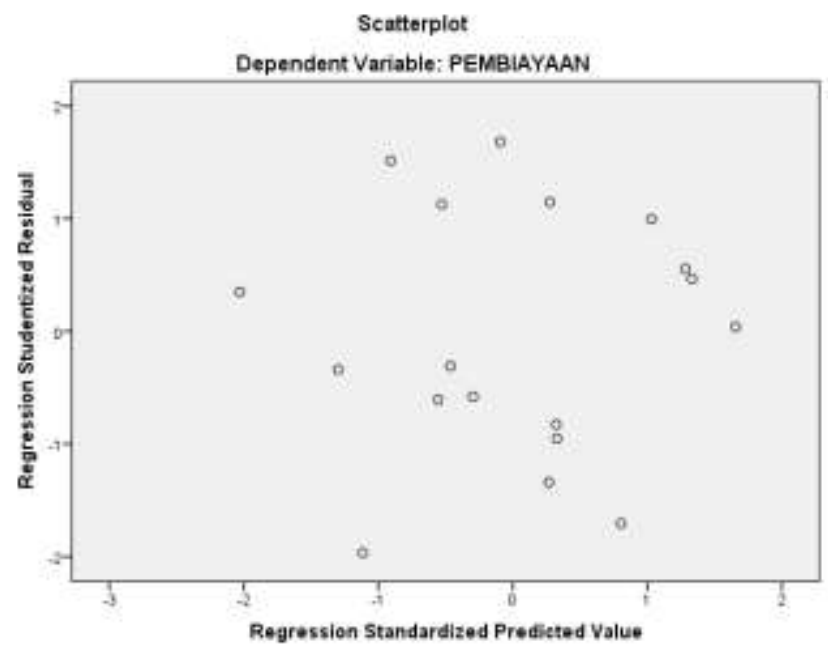

Gambar 2. Hasil Uji Heteroskedastisitas

Pada gambar di atas dapat dilihat bahwa titik-titik menyebar di atas dan dibawah sumbu Y. maka dapat disimpulkan bahwa data yang digunakan tidak terjadi heteroskedastisitas. 
d) Uji Autokorelasi

Tabel 4: Hasil Uji Autokorelasi

\begin{tabular}{lr}
\multicolumn{2}{c}{ Runs Test } \\
\hline & $\begin{array}{c}\text { Unstandardized } \\
\text { Residual }\end{array}$ \\
\hline Test Value $^{\mathrm{a}}$ & $-133759,46638$ \\
Cases < Test Value & 9 \\
Cases >= Test Value & 9 \\
Total Cases & 18 \\
Number of Runs & 8 \\
Z &,- 729 \\
Asymp. Sig. (2-tailed) &, 466 \\
\hline a. Median & \\
\hline
\end{tabular}

Dari tabel di atas dapat dilihat nilai Asymp. Sig. (2-tailed) yaitu 0,466. Dimana nilai tersebut lebih besar dari 0,05 maka data yang digunakan tidak terjadi gejala autokorelasi.

\section{Analisis Regresi Linier Berganda}

Analisis regresi linear berganda dilakukan untuk mengetahui pengaruh dua atau lebih variabel independen terhadap variabel dependen. Persamaan dalam regresi linear berganda adalah $\mathrm{Y}=\mathrm{a}+\mathrm{b}_{1} \mathrm{X}_{1}+\mathrm{b}_{2} \mathrm{X}_{2}+\mathrm{b}_{3} \mathrm{X}_{3}$. Dengan menggunakan software IBM SPSS 21, diperoleh nilai-nilai koefisien regresi sebagai berikut:

Tabel 5. Hasil Analisis Regresi Linier Berganda

\begin{tabular}{|c|c|c|c|c|c|c|}
\hline \multicolumn{7}{|c|}{ Coefficients $^{\mathbf{a}}$} \\
\hline \multicolumn{2}{|c|}{ Model } & \multicolumn{2}{|c|}{ Unstandardized Coefficients } & \multirow{2}{*}{$\begin{array}{c}\text { Standardized } \\
\text { Coefficients } \\
\text { Beta }\end{array}$} & \multirow[t]{2}{*}{$\mathrm{t}$} & \multirow[t]{2}{*}{ Sig. } \\
\hline & & $\mathrm{B}$ & Std. Error & & & \\
\hline \multirow{4}{*}{1} & (Constant) & 2646151,386 & 2515162,883 & & 1,052 & ,311 \\
\hline & DPK &, 543 &, 215 &, 576 & 2,529 & 024 \\
\hline & NPF & $-41857,959$ & 454946,203 &,- 025 &,- 092 & ,928 \\
\hline & ROA & 202860,065 & 4630977,513 &, 012 &, 044 & ,966 \\
\hline
\end{tabular}

a. Dependent Variable: PEMBIAYAAN

Dimana Pembiyaan sebagai (Y) dan Dana Pihak Ketiga (DPK), Non Performing Financing (NPF) dan Return On Asset (ROA) adalah sebagai ( $\left.\mathrm{X}_{1}, \mathrm{X}_{2}, \mathrm{X}_{3}\right)$. Maka persamaannya adalah $\mathrm{Y}=2646151,386+0,543-41857,959+202860,065$. Dari persamaan regresi di atas dapat diinterpretasikan sebagai berikut: 
a. Konstanta sebesar 2646151,386 menyatakan bahwa jika nilai variabel DPK ( $\left.\mathrm{X}_{1}\right)$, NPF $\left(\mathrm{X}_{2}\right)$ dan ROA $\left(\mathrm{X}_{3}\right)$ sama dengan nol atau konstan, maka besarnya nilai Pembiayaan (Y) yaitu 2646151,386.

b. Nilai koefisien regresi $X_{1}$ sebesar 0,543 menyatakan bahwa setiap penambahan 1 satuan dari Dana Pihak Ketiga (DPK) maka akan menaikan Pembiayaan sebesar 0,543 dan sebaliknya, jika setiap penurunan 1 satuan DPK maka Pembiayaan akan mengalami penurunan sebesar 0,543 .

c. Nilai koefisien regresi $\mathrm{X}_{2}$ sebesar $-41857,959$ menyatakan bahwa setiap penambahan 1 satuan Non Performing Financing (NPF) maka akan menurunkan Pembiayaan sebesar -41857,959 dan sebaliknya, jika setiap penurunan 1 satuan NPF maka Pembiayaan akan mengalami peningkatan sebesar -41857,959.

d. Nilai koefisien regresi $X_{3}$ sebesar 202860,065 menyatakan bahwa setiap penambahan 1 satuan dari Return On Asset (ROA) maka akan menaikan Pembiayaan sebesar -202860,065 dan sebaliknya, jika setiap penurunan 1 satuan ROA maka Pembiayaan akan mengalami penurunan sebesar 202860,065.

\section{Pengujian Hipotesis}

a) Uji Parsial (Uji t)

\begin{tabular}{cccc}
\multicolumn{4}{c}{$\begin{array}{c}\text { Tabel 6. Hasil Uji t } \\
\text { Coefficients }^{\mathbf{a}}\end{array}$} \\
\hline Model & $\mathrm{T}$ & Sig. \\
& & & \\
\hline & (Constant) & 1,052 &, 311 \\
1 & DPK & 2,529 &, 024 \\
& NPF &,- 092 &, 928 \\
& ROA &, 044 &, 966 \\
\hline \multicolumn{2}{l}{ a. Dependent Variable: PEMBIAYAAN } \\
\hline
\end{tabular}

Dari hasil uji $t$ regresi linear berganda di atas dapat ditarik kesimpulan sebagai berikut:

1) thitung variabel Dana Pihak Ketiga (DPK) sebesar 2,529 dan tabel sebesar 2,10982, jadi 2,529 > 2,10982. Dan signifikansi DPK sebesar 0,024<0,05. Dapat disimpulkan bahwa $\mathrm{H}_{\mathrm{a}}$ diterima dan $\mathrm{H}_{0}$ ditolak, artinya Dana Pihak Ketiga (DPK) berpengaruh positif secara parsial terhadap Pembiayaan.

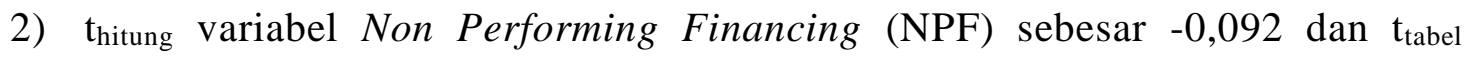
sebesar 2,10982, jadi -0,092 < 2,10982. Dan signifikansi NPF sebesar 0,928> 0,05. Dapat disimpulkan bahwa $\mathrm{H}_{0}$ diterima dan $\mathrm{H}_{\mathrm{a}}$ ditolak, artinya Non Performing Financing (NPF) tidak berpengaruh negatif secara parsial terhadap Pembiayaan.

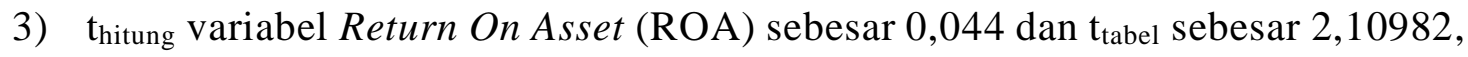
jadi $0,044<2,109829$. Dan signifikansi ROA sebesar 0,966>0,05. Dapat 
disimpulkan bahwa $\mathrm{H}_{0}$ diterima dan $\mathrm{H}_{\mathrm{a}}$ ditolak, artinya Return On Asset (ROA) tidak berpengaruh positif secara parsial terhadap Pembiayaan.

b) Uji Simultan (Uji F)

Tabel 7: Hasil Uji F

ANOVA ${ }^{a}$

\begin{tabular}{|c|c|c|c|c|c|c|}
\hline \multicolumn{2}{|c|}{ Model } & $\begin{array}{l}\text { Sum of } \\
\text { Squares }\end{array}$ & $\mathrm{df}$ & Mean Square & $\mathrm{F}$ & Sig. \\
\hline \multirow{6}{*}{1} & \multirow{2}{*}{ Regression } & 1804909471 & 3 & 6016364905 & \multirow[t]{6}{*}{2,307} & \multirow[t]{6}{*}{, $121^{\mathrm{b}}$} \\
\hline & & 6071,610 & & 357,203 & & \\
\hline & \multirow{2}{*}{ Residual } & 3651527768 & 14 & 2608234120 & & \\
\hline & & 8626,695 & & 616,192 & & \\
\hline & \multirow{2}{*}{ Total } & 5456437240 & 17 & & & \\
\hline & & 4698,305 & & & & \\
\hline \multicolumn{7}{|c|}{ a. Dependent Variable: PEMBIAYAAN } \\
\hline \multicolumn{7}{|c|}{ b. Predictors: (Constant), ROA, DPK, NPF } \\
\hline
\end{tabular}

Berdasarkan tabel di atas, nilai F hitung adalah sebesar 2,307. Karena F hitung < F tabel sebesar 3,23, maka sebagaimana dasar pengambilan keputusan dalam uji F dapat disimpulkan bahwa Dana Pihak Ketiga (DPK), Non Performing Financing (NPF) dan Return On Asset (ROA) secara simultan tidak berpengaruh terhadap Pembiayaan.

c) Uji Koefisien Determinasi $\left(\mathrm{Uji}^{2}\right)$

Tabel 8: Hasil Uji $\mathrm{R}^{2}$

\begin{tabular}{lrrrr}
\multicolumn{5}{c}{ Model Summary } \\
\hline Model & R & R Square & $\begin{array}{c}\text { Adjusted R } \\
\text { Square }\end{array}$ & $\begin{array}{l}\text { Std. Error of } \\
\text { the Estimate }\end{array}$ \\
\hline & & &, 187 & 1615002,823 \\
1 &, $575^{\mathrm{a}}$ &, 331 & & 72 \\
\hline \multicolumn{4}{l}{ a. Predictors: (Constant), ROA, DPK, NPF } \\
\hline
\end{tabular}

Berdasarkan tabel di atas menunjukkan bahwa nilai Adjusted $R$ Square sebesar 0,187 artinya sebesar 18,7\% menunjukkan bahwa Dana Pihak Ketiga (DPK), Non Performing Financing (NPF) dan Return On Asset (ROA) berpengaruh secara bersamasama terhadap Pembiayaan di PT Bank Muamalat Indonesia Tbk.

\section{E. KESIMPULAN}

Berdasarkan hasil penelitian mengenai pengaruh Dana Pihak Ketiga (DPK), Non Performing Financing (NPF) dan Return On Asset (ROA) terhadap Pembiayaan pada PT Bank 
Muamalat Indonesia Tbk periode 2016-2020, berdasarkan hasil analisis data dan pembahasan yang telah diuraikan sebelumnya, maka dapat diambil kesimpulan sebagai berikut:

1. Dana Pihak Ketiga (DPK) berpengaruh positif secara parsial terhadap Pembiayaan pada PT Bank Muamalat Indonesia Tbk periode Triwulan I 2016 - Triwulan III 2020.

2. Non Performing Financing (NPF) tidak berpengaruh negatif secara parsial terhadap Pembiayaan p pada PT Bank Muamalat Indonesia Tbk periode Triwulan I 2016 - Triwulan III 2020.

3. Return On Asset (ROA) tidak berpengaruh positif secara parsial terhadap Pembiayaan pada PT Bank Muamalat Indonesia Tbk periode Triwulan I 2016 - Triwulan III 2020.

4. Dana Pihak Ketiga (DPK), Non Performing Financing (NPF) dan Return On Asset (ROA) secara simultan tidak berpengaruh terhadap Pembiayaan pada PT Bank Muamalat Indonesia Tbk periode Triwulan I 2016 - Triwulan III 2020.

Keterbatasan Penelitian

1. Dalam penelitian ini hanya meneliti tiga variabel bebas yaitu Dana Pihak Ketiga (DPK), Non Performing Financing (NPF) dan Return On Asset (ROA) dan satu variabel terikat yaitu Pembiayaan.

2. Keterbatasan jumlah sampel yang digunakan.

3. Nilai $R$ Square yang masih rendah.

Saran

1. Penelitian yang akan datang hendaknya menambah variabel penelitian.

2. Dalam penelitian selanjutnya diharapkan agar menambah jumlah sampel. 


\section{DAFTAR PUSTAKA}

Anwar, C., \& Miqdad, M. (2017). "Pengaruh Dana Pihak Ketiga (DPK), Capital Adequacy Ratio (CAR), Return On Asset (ROA) Terhadap Pembiayaan Mudharabah Pada Bank Umum Syariah Tahun 2008 - 2012”. Riset dan Jurnal Akuntansi, I(1).

Aziza, R. V., \& Mulazid, A. S. (2017). “Analisis Pengaruh Dana Pihak Ketiga, Non Performing Financing, Capital Adequacy Ratio, Modal Sendiri dan Marjin Keuntungan terhadap Pembiayaan Murabahah". Jurnal Ekonomi dan Bisnis Islam, II(1).

Destiana, R. (2016). "Analisis Dana Pihak Ketiga dan Risiko Terhadap Pembiayaan Mudharabah dan Musyarakah Pada Bank Syariah di Indonesia". Jurnal Logika, XVII(2), 42-54.

Erlita, R. R. (2016). "Pengaruh DPK, NPF, CAR, Ekuivalen Bagi Hasil, dan Sertifikat IMA Terhadap Pembiayaan Bank Umum Syariah Tahun 2012-2014”. Jurnal Kajian Bisnis, 167-180.

Ghozali, Imam (2005). Analisis Multivariate Dengan Program SPSS. Semarang: Badan Penerbit Universitas Diponegoro.

Khotimah, A. K. (2019). "Pengaruh Dana Pihak Ketiga, Financing to Deposit Ratio, Captal Adequancy Ratio, dan Non Performing Financing Terhadap Profitabilitas dengan Pembiayaan sebagai Variabel Intervening (Studi Kasus Pada Bank Umum Syariah Periode 2013-2017)". Skripsi. Salatiga: IAIN Salatiga

Muhammad. (2004). Teknik Perhitungan Bagi Hasil dan Profit Margin pada Bank Syariah. Yogyakarta: UII Press.

Muhammad. (2017). Metodologi Penelitian Ekonomi Islam: Pendekatan Kuantitatif. Bandung: PT RajaGrafindo Persada.

Ovami, D. C., \& Thohari, A. A. (2018). "Pengaruh Dana Pihak Ketiga Dan Non Performing Financing Terhadap Pembiayaan Musyarakah”. Jurnal Penelitian Pendidikan Sosial Humaniora, III(1).

Pasaribu, D. O. (2019). "Pengaruh FDR, NPF, ROA dan BOPO Terhadap Pembiayaan

Mudharabah Bank Umum Syariah di Indonesia". Tesis. Medan: Universitas Muhammadiyah Sumatera Utara.

Riyadi, S., \& Rafii, R. M. (2018). "Pengaruh Dana Pihak Ketiga, Capital Adequacy Ratio, Bi Rate, Dan Financing To Deposit Ratio Terhadap Pembiayaan Murabahah Pada Bank Syariah Di Indonesia". Perbanas Review, III(2), 65-82.

Setiawan, Ulin Nuha Aji dan Astiwi Indriani. (2016). "Pengaruh Dana Pihak Ketiga (DPK), Capital Adequacy Ratio (CAR), dan Non Performing Financing (NPF) terhadap Profitabilitas Bank Syariah dengan Pembiayaan sebagai Variabel Intervening”. Diponegoro Journal Of Management. Volume 5, Nomor 4, Hal: 1-11.

Sugiyono. (2016). Metode Penelitian Kuantitatif, Kualitatif, dan R\&D. Bandung: ALFABETA. Supranto, J. (2008). Statistik Teori dan Aplikasi: Edisi Ketujuh Jilid 1. Jakarta: Erlangga. www.bankmuamalat.co.id diakses pada tanggal 17 Maret 2021 pukul 10:20.

www.ojk.go.id diakses pada tanggal 17 Maret 2021 pukul 17:13. 